\title{
STUDI PENGOLAHAN LIMBAH CAIR DOMESTIK DENGAN BIOFILTER MEDIA
}

\section{IJUK}

\author{
I Wayan Eka Parama Putra, I Gede Herry Purnama* \\ Program Studi Sarjana Kesehatan Masyarakat, Fakultas Kedokteran, Universitas Udayana \\ Alamat: Jalan PB. Sudirman, Denpasar, Bali 80232
}

\begin{abstract}
ABSTRAK
Hotel di kawasan pariwisata merupakan salah satu sumber penghasil limbah cair domestik. Pengolahan limbah cair domestik dilakukan untuk mencegah terjadinya pencemaran lingkungan. Penelitian ini bertujuan untuk mengetahui efektivitas penggunaan ijuk sebagai media biofilter untuk mengolah limbah cair domestik dari hotel. Desain penelitian yang digunakan adalah kuasi eksperimental. Data yang digunakan pada penelitian ini adalah data primer dari hasil pengujian laboratorium. Pada penelitian ini parameter yang akan diteliti adalah BOD5, COD, TDS, dan pH. Berdasarkan sampel yang diambil di salah satu hotel di Kota Denpasar, nilai rata-rata parameternya antara lain: BOD5 sebesar 86,71 mg/L, COD sebesar 122,3 mg/L, TDS sebesar $529 \mathrm{mg} / \mathrm{L}$, dan pH 8. Sebelum diuji dilakukan seeding selama 2 minggu untuk menumbuhkan bakteri di dalam reaktor. Efektivitas sistem yang diperoleh selama 5 minggu pengujian memiliki nilai rata-rata sebesar 33,05\%, dengan persentase efektivitas penurunan parameter pencemar antara lain: BOD sebesar 46,47\%, COD sebesar 39,88\%, TDS sebesar $12,81 \%$. Terdapat beberapa faktor yang mempengaruhi kinerja reaktor seperti: air limbah yang dipergunakan memiliki kualitas yang fluktuatif, cara penyusunan media biofilter, dan kondisi lingkungan saat penelitian dilakukan.
\end{abstract}

Kata Kunci: Ijuk, Biofilter, Air Limbah Domestik

\begin{abstract}
Hotels in tourism areas are a source of domestic wastewater. Domestic wastewater treatment is carried out to prevent environmental pollution. This study aims to determine the effectiveness of using palm fiber as a biofilter medium to treat domestic wastewater from hotels. The research design used was quasi experimental. The data used in this study are primary data from laboratory test results. In this study, the parameters to be studied are $\mathrm{BOD}_{2}$, COD, TDS, and $\mathrm{pH}$. Based on samples taken at a hotel in Denpasar City, the average parameter values include: BOD5 of $86.71 \mathrm{mg} / \mathrm{L}$, COD of $122.3 \mathrm{mg} / \mathrm{L}$, TDS of $529 \mathrm{mg} / \mathrm{L}$, and $\mathrm{pH}$ of 8 . Before being tested, seeding was carried out for 2 weeks to grow bacteria in the reactor. The system effectiveness obtained during the 5 weeks of testing has an average value of $33.05 \%$, with the percentage of effectiveness of decreasing pollutant parameters, among others: BOD of $46.47 \%$, COD of $39.88 \%$, TDS of $12.81 \%$. There are several factors that affect the performance of the reactor, such as: the quality of the wastewater used is fluctuating, the way the biofilter media is prepared, and the environmental conditions when the research is carried out.
\end{abstract}

Keywords: Palm Fibers, Biofilter, Domestic Wastewater

\section{PENDAHULUAN}

Limbah cair domestik merupakan limbah yang berasal dari aktivitas hidup masyarakat sehari-hari, air limbah domestik terdiri dari limbah tubuh manusia (kotoran dan air seni), air yang digunakan untuk pembilasan toilet serta air limbah yang berasal dari kegiatan mandi, air cucian, pembersihan peralatan dapur serta air limbah yang berasal dari kegiatan sehari - hari lainnya (Mara, 2004).

Bali merupakan salah satu tujuan wisata di Indonesia yang banyak E-mail korespondensi: herrypurnama@unud.ac.id dikunjungi oleh wisatawan mancanegara maupun lokal. Berdasarkan data Badan Pusat Statistik Provinsi Bali pada tahun 2019 jumlah wisatawan asing yang datang ke Bali yaitu mencapai 6.275.210 jiwa. Sedangkan fasilitas pariwisata yang tersedia yaitu 551 hotel berbintang dan 4323 hotel non bintang dan akomodasi lainnya yang tersebar di seluruh Bali.

Konsumsi air bersih untuk hotel mencapai 1000 liter/kamar/hari, sedangkan untuk restoran mencapai 5 liter/tempat duduk/hari yang mana $70 \%$ dari jumlah 
konsumsi air tersebut terbuang menjadi limbah (Budiarta, 2014). Rata - rata limbah cair yang dihasilkan oleh hotel bintang lima yang berada di kabupaten Badung mencapai 364,4 m3/hari (Pitoyo dkk., 2016). Peningkatan pemakaian air dalam berbagai kegiatan sehari-hari akan menghasilkan sisa buangan berupa limbah, 85\% limbah yang dihasilkan masuk ke badan perairan yang mengakibatkan selfpurification tidak berjalan dengan seimbang. Limbah cair merupakan limbah yang terdiri dari 99,9\% air dan sisanya bahan padat (Pungus dkk., 2019). Banyaknya air limbah yang dihasilkan dan tingginya kandungan beban organik memiliki potensi pencemaran lingkungan yang serius (Mishra dkk., 2015).

Salah satu sistem pengolahan limbah cair yang dapat diterapkan yaitu dengan sistem biofilter. Pada sistem biofilter terjadi proses pengolahan untuk mendegradasi bahan organik yang terkandung dalam air limbah. Proses biologis yang terjadi akan membentuk lapisan biofilm yang melekat pada media biofilter sebagai oksidator yang mengakibatkan bahan organik terlarut mengalami reaksi oksidasi reduksi dengan bantuan mikroorganisme (Yuliani, 2018).

Media yang dipergunakan dalam sistem biofilter memiliki pengaruh terhadap hasil pengolahan air limbah. Media ijuk merupakan salah satu media filtrasi dengan kemampuan yang baik dalam proses pengolahan air. Ijuk memiliki daya tahan yang kuat dan umur produk yang lama, serta serat ijuk merupakan serat yang tahan terhadap asam dan garam air laut (Widyawati, 2011). Berdasarkan hal tersebut dan minimnya studi terkait dengan penggunaan ijuk sebagai media utama biofilter, maka peneliti ingin melihat bagaimana efektivitas penggunaan ijuk sebagai media biofilter untuk mengolah air limbah domestik.

\section{METODE PENELITIAN}

Penelitian ini menggunakan penelitian kuasi eksperimental, untuk melihat bagaimana efektivitas dari penggunaan ijuk sebagai media biofilter dalam mengolah air limbah domestik fasilitas pariwisata (hotel) dengan melakukan pengulangan sebanyak 3 kali. Selanjutnya untuk melihat efektivitas dari instalasi pengolahan air limbah akan dilakukan pengujian parameter BOD, COD, TDS dan $\mathrm{pH}$ di laboratorium. Uji laboratorium akan dilakukan 2 tahap, tahap pertama air limbah sebelum dilakukan pengolahan, tahap kedua dilakukan setelah dilakukan pengolahan setiap minggu sebanyak 5 kali.

Reaktor yang akan dipergunakan dalam sistem biofilter ini menggunakan bahan kaca yang memiliki kapasitas 91,8 liter dengan tinggi $35 \mathrm{~cm}$, panjang $75 \mathrm{~cm}$, dan lebar $35 \mathrm{~cm}$. Reaktor biofilter yang dibuat memiliki 3 kompartemen. Air limbah yang ada di dalam reaktor dialirkan secara upflow. Pada bagian dasar terdapat selang aerator untuk menyalurkan oksigen sehingga mikroorganisme dalam reaktor dalam kondisi aerob. Air limbah ditampung mempergunakan bak plastik dengan kapasitas $150 \quad$ liter. 
Air limbah dialirkan secara gravitasi dari bak penampung ke dalam reaktor dengan HRT sebesar $54 \mathrm{ml}$ per menit.

Sebelum reaktor dipergunakan dilakukan proses startup, Pada saat startup reaktor terdapat proses seeding yang bertujuan untuk menumbuhkan mikroorganisme pada media yang terdapat pada reaktor. Proses seeding ini dilakukan secara alami dengan cara mengalirkan air limbah domestik yang berasal dari hotel secara kontinyu ke dalam reaktor biofilter sehingga terbentuk lapisan biofilm pada media ijuk.

\section{HASIL}

\section{Kualitas Parameter BOD}

Berdasarkan hasil pengujian yang dilakukan selama 5 minggu, penurunan parameter BOD yang diperoleh dapat dilihat pada tabel 1 .

Tabel 1. Nilai Penurunan Parameter BOD

\begin{tabular}{cccc}
\hline & \multicolumn{2}{c}{$\begin{array}{c}\text { Nilai Parameter } \\
\text { Sampel }\end{array}$} & \multicolumn{2}{c}{ NE } \\
& BOD & BOD & $(\%)$ \\
& Influent & Effluent & \\
\hline M1 & 86,71 & 36,95 & 57,38 \\
M2 & 92,34 & 33,09 & 64,17 \\
M3 & 36,10 & 30,69 & 14,98 \\
M4 & 43,17 & 24,43 & 43,40 \\
M5 & 68,70 & 32,67 & 52,44 \\
Aм1-M5 & 65,40 & 31,57 & 46,47 \\
\hline
\end{tabular}

Keterangan: $\mathrm{M}=\mathrm{Minggu}, \mathrm{Am}_{\mathrm{m}-\mathrm{m} 5=\text { Rata-rata }}$ nilai dari minggu 1 sampai 5, NE = Nilai Efektivitas.

Berdasarkan hasil yang terdapat pada tabel 1, nilai parameter BOD sebelum pengolahan memiliki nilai parameter yang cukup tinggi dan belum sesuai dengan E-mail korespondensi: herrypurnama@unud.ac.id kriteria standar yang ditetapkan pada Peraturan Gubernur Bali No. 16 Tahun 2016 yaitu sebesar $28 \mathrm{mg} / \mathrm{L}$. Nilai parameter BOD sebelum pengolahan tertinggi memiliki nilai sebesar $92,34 \mathrm{mg} / \mathrm{L}$ dan pada minggu 3 nilai parameter BOD sebelum pengolahan mengalami penurunan yang signifikan sehingga memiliki nilai terendah yaitu 36,10 mg/L. Rata-rata nilai parameter BOD sebelum Pengolahan selama 5 minggu yaitu sebesar 65,40 mg/L. Nilai parameter BOD setelah pengolahan selama 5 minggu rata-rata mengalami penurunan setiap minggunya. Pada minggu ke-4 nilai rata- rata pengolahan sudah sesuai dengan baku mutu yang berlaku.

Dari hasil yang diperoleh persentase efektivitas penurunan parameter BOD mengalami fluktuasi setiap minggunya. Pada minggu 1 dan 2 persentase efektivitasnya sudah cukup baik namun pada minggu ke-3 mengalami penurunan efektivitas. Persentase efektivitas penurunan parameter BOD tertinggi terjadi pada minggu ke-2 yaitu sebesar $64,17 \%$ dan persentase terendah terjadi pada minggu ke-3 sebesar 14,98\%. Persentase efektivitas penurunan parameter BOD selama 5 minggu memiliki nilai rata-rata sebesar $46,47 \%$.

\section{Kualitas Parameter COD}

Berdasarkan hasil pengujian yang dilakukan selama 5 minggu, penurunan parameter COD yang diperoleh dapat dilihat pada tabel 2 . 
Tabel 2. Nilai Penurunan Parameter COD

\begin{tabular}{cccc}
\hline \multirow{3}{*}{$\begin{array}{c}\text { Nilai Parameter } \\
\text { Sampel }\end{array}$} & \multirow{2}{c}{$\begin{array}{c}\text { NE } \\
\text { COD }\end{array}$} & COD & $(\%)$ \\
& Enfluent & Effluent & \\
\hline M1 & 122,30 & 61,39 & 49,81 \\
M2 & 164,36 & 58,87 & 64,18 \\
M3 & 56,71 & 54,29 & 4,27 \\
M4 & 67,84 & 42,76 & 36,98 \\
M5 & 92,45 & 51,63 & 44,15 \\
AM1-M5 & 100,73 & 53,79 & 39,88 \\
\hline
\end{tabular}

Keterangan: $\mathrm{M}=\mathrm{Minggu}, \mathrm{Am}_{\mathrm{m}-\mathrm{M} 5}=$ Rata-rata nilai dari minggu 1 sampai 5, NE = Nilai Efektivitas.

Berdasarkan hasil yang terdapat pada tabel 2 nilai parameter COD sebelum pengolahan memiliki nilai parameter yang tinggi dan belum sesuai dengan kriteria standar yang ditetapkan pada Peraturan Gubernur Bali No. 16 Tahun 2016 yaitu sebesar $50 \mathrm{mg} / \mathrm{L}$. Nilai parameter COD sebelum pengolahan tertinggi memiliki nilai sebesar 164,36 mg/L dan pada minggu 3 nilai parameter COD sebelum pengolahan mengalami penurunan yang signifikan sehingga memiliki nilai terendah sebesar 54,29 $\mathrm{mg} / \mathrm{L}$. Rata-rata nilai parameter COD sebelum Pengolahan selama 5 minggu yaitu sebesar 100,73 $\mathrm{mg} / \mathrm{L}$. Nilai parameter COD setelah pengolahan selama 5 minggu rata-rata mengalami penurunan setiap minggunya dan memiliki hasil yang lebih baik apabila dibandingkan dengan air limbah sebelum diolah. Pada minggu ke-4 nilai parameter COD sudah memenuhi baku mutu yang berlaku dimana hasil yang didapat yaitu sebesar $42,76 \mathrm{mg} / \mathrm{L}$.

E-mail korespondensi: herrypurnama@unud.ac.id
Dari hasil yang diperoleh persentase efektivitas penurunan parameter COD mengalami fluktuasi setiap minggunya dan hampir sama dengan parameter BOD. Pada minggu 1 dan 2 persentase efektivitasnya sudah cukup baik namun pada minggu ke-3 mengalami penurunan efektivitas. Persentase efektivitas penurunan parameter COD tertinggi terjadi pada minggu ke-2 yaitu sebesar $64,18 \%$ dan persentase terendah terjadi pada minggu ke-3 sebesar $4,27 \%$. Persentase efektivitas penurunan parameter COD selama 5 minggu memiliki nilai rata-rata sebesar $39,88 \%$.

\section{Kualitas Parameter TDS}

Berdasarkan hasil pengujian yang dilakukan selama 5 minggu, penurunan parameter TDS yang diperoleh dapat dilihat pada tabel 3.

Tabel 3. Nilai Penurunan Parameter TDS

\begin{tabular}{cccc}
\hline & \multicolumn{2}{c}{$\begin{array}{c}\text { Nilai Parameter } \\
(\mathrm{mg} / \mathrm{L})\end{array}$} & \multirow{2}{*}{$\begin{array}{c}\text { NE } \\
\text { Sampel }\end{array}$} \\
\cline { 2 - 3 } & $\begin{array}{c}\text { TDS } \\
\text { Influent }\end{array}$ & $\begin{array}{c}\text { TDS } \\
\text { Effluent }\end{array}$ \\
\hline M1 & 533 & 414 & 22,33 \\
M2 & 490 & 434,33 & 11,36 \\
M3 & 489 & 434 & 11,25 \\
M4 & 453 & 404,67 & 10,67 \\
M5 & 450 & 412 & 8,44 \\
Am1-M5 & 483 & 419,8 & 12,81 \\
\hline
\end{tabular}

Keterangan: $\mathrm{M}=\mathrm{Minggu}, \mathrm{A}_{\mathrm{M} 1-\mathrm{M} 5}=$ Rata-rata nilai dari minggu 1 sampai $5, \mathrm{NE}=$ Nilai Efektivitas.

Berdasarkan hasil yang terdapat pada tabel 3 nilai parameter TDS sebelum pengolahan memiliki nilai parameter yang sudah sesuai dengan kriteria standar yang ditetapkan pada Peraturan Gubernur Bali 
No. 16 Tahun 2016 yaitu sebesar 2000 $\mathrm{mg} / \mathrm{L}$. Nilai parameter TDS sebelum pengolahan tertinggi memiliki nilai sebesar $533 \mathrm{mg} / \mathrm{L}$ Rata-rata nilai parameter TDS sebelum Pengolahan selama 5 minggu yaitu sebesar $483 \mathrm{mg} / \mathrm{L}$. Nilai parameter TDS setelah pengolahan selama 5 minggu rata-rata mengalami penurunan setiap minggunya dan memiliki hasil yang lebih baik apabila dibandingkan dengan air limbah sebelum diolah. Hasil dari pengolahan selama 5 minggu pengolahan rata-rata memiliki nilai yang sudah sesuai dengan baku mutu yang berlaku.

Apabila dilihat dari tabel 3 selama 5 minggu pengujian hasil efektivitas yang diperoleh mengalami penurunan setiap minggunya. Nilai persentase efektivitas penurunan TDS tertinggi terjadi pada minggu 1 sebesar $22,33 \%$ dan persentase terendah terjadi pada minggu ke- 5 sebesar $8,44 \%$. Rata-rata persentase efektivitas penurunan TDS Selama 5 minggu yaitu sebesar $12,81 \%$.

\section{Kualitas Parameter pH}

Berdasarkan hasil penelitian yang dilakukan nilai $\mathrm{pH}$ pada air limbah sebelum dilakukan pengolahan memiliki nilai rata-rata sebesar 8,5. Apabila dibandingkan dengan baku mutu yang berlaku nilai tersebut sudah sesuai dengan kriteria yang ditentukan, dimana baku mutu untuk nilai $\mathrm{pH}$ berkisar antara 6-9. Setelah dilakukan pengolahan $\mathrm{pH}$ air limbah memiliki rata-rata nilai sebesar 8,2 dan sudah sesuai dengan baku mutu yang berlaku.

\section{DISKUSI}

\section{Kondisi Air Limbah Domestik Hotel Sebelum Pengolahan}

E-mail korespondensi: herrypurnama@unud.ac.id
Berdasarkan hasil penelitian yang dilakukan, kualitas air limbah domestik dari salah satu hotel yang terletak di Kawasan Jalan Gatot Subroto Kota Denpasar sudah memenuhi baku mutu untuk parameter $\mathrm{pH}$. Rata-rata nilai parameter $\mathrm{pH}$ sebesar 8,5 yang hampir mendekati basa namun masih memenuhi kriteria baku mutu yaitu 6-9. Parameter TDS memiliki nilai rata-rata parameter 483 $\mathrm{mg} / \mathrm{L}$. Sedangkan parameter BOD dan COD memiliki nilai rata-rata yang tinggi.

Pada parameter BOD5 memiliki nilai rata-rata parameter sebesar 65,40 $\mathrm{mg} / \mathrm{L}$. Sedangkan pada parameter COD memiliki nilai rata - rata parameter yang tinggi yaitu sebesar 100,73 mg/L. Kedua parameter ini masih belum sesuai dengan kriteria baku mutu standar yang ditetapkan pada Peraturan Gubernur Bali No. 16 Tahun 2016 dimana untuk nilai parameter BOD yang diperbolehkan yaitu sebesar $28 \mathrm{mg} / \mathrm{L}$ dan untuk COD sebesar 50 mg/L. Tingginya kandungan BOD dan COD dalam air limbah disebabkan oleh kandungan bahan organik yang terdapat di dalamnya, semakin tinggi kandungan BOD dan COD maka semakin banyak oksigen yang diperlukan untuk mendegradasi bahan organik yang tersebut (Rarasari dkk., 2019)

\section{Efektivitas Pengolahan Selama 5 Minggu}

Berdasarkan tabel 1 dan 2 terlihat persentase efektivitas penurunan BOD dan COD pada seluruh reaktor mengalami penurunan pada minggu ke 3 kemudian mengalami peningkatan pada minggu selanjutnya. Hal ini dipengaruhi oleh variasi kualitas air limbah sebelum diolah yang dimasukan ke dalam reaktor. Variasi 
kualitas air limbah pada penelitian ini tidak dapat dikontrol. Pada saat melakukan penelitian terjadi pandemi COVID-19, pandemi ini mengakibatkan terjadinya pembatasan pergerakan masyarakat sehingga kunjungan ke hotel tersebut menurun dan berpengaruh terhadap jenis kegiatan yang dilakukan di hotel tersebut. terjadinya perubahan tersebut mempengaruhi kualitas dan kuantitas air limbah yang dihasilkan seperti adanya penurunan bahan organik dalam air limbah. Apabila melihat hasil pengujian pada tabel 1 dan 2 nilai parameter sebelum pengolahan mengalami penurunan yang signifikan pada minggu ke 3 dan mulai meningkat pada minggu selanjutnya. Hal tersebut mempengaruhi nilai persentase efektivitas yang didapat, dimana terjadi penurunan nilai persentase efektivitas di minggu ke 3 pada seluruh reaktor. Berdasarkan tabel 3 efektivitas penurunan TDS tidak berjalan dengan maksimal, efektivitas yang diperoleh mengalami penurunan setiap minggunya. Efektivitas penurunan TDS dapat berjalan maksimal apabila mikroorganisme mampu menguraikan bahan organik dan anorganik dengan baik dan kondisi pada sistem filter tidak mengalami penyumbatan yang diakibatkan oleh endapan-endapan bahan organik pada air limbah (Fitriana \& Weliyadi, 2016).

Di dalam lapisan biofilm terjadi reaksi metabolisme mikroorganisme yang memungkinkan terjadinya mekanisme pertumbuhan, pemeliharaan, kematian, dan lisis sel (Grady, 1980). Kehidupan mikroorganisme di dalam reaktor sangat dipengaruhi oleh kondisi lingkungannya, sehingga dalam pengolahan air limbah secara biologi harus memperhatikan lingkungan mikroorganisme diantaranya: derajat keasaman $(\mathrm{pH})$, temperatur, bahan makanan (nutrisi) dan kebutuhan oksigen. Perubahan kualitas air limbah yang dihasilkan pada minggu ke 3 berpengaruh terhadap efektivitas reaktor dimana terjadi penurunan suplai nutrisi untuk mikroorganisme yang ada di dalam reaktor. Penurunan jumlah nutrient seperti nitrogen dan phospor cenderung menyebabkan penurunan pertumbuhan mikroorganisme di dalam reaktor (Bagus, 2008)

Selain terjadinya perubahan kualitas air limbah, pada saat penelitian berlangsung, hampir setiap minggu turun hujan. Pada penelitian ini reaktor diletakkan diluar ruangan sehingga temperatur air limbah di dalam reaktor mengalami perubahan sesuai dengan kondisi cuaca. Saat turun hujan kondisi temperatur akan mengalami penurunan. Menurut Slamet dan Masduqi (2000), Pengaruh temperatur memberikan efek yang berlawanan pada proses aerobik biofilm. Laju difusi nutrisi dan oksigen akan naik seiring dengan kenaikan temperatur namun disisi lain laju kelarutan oksigen menurun. Temperatur memberikan pengaruh pada proses pertumbuhan biofilm. Pengaruh temperatur pada proses nitrifikasi telah dikaji bahwa pada attached growth dapat mencapai laju nitrifikasi $>70 \%$ pada range temperatur $250 \mathrm{C}-300 \mathrm{C}$.

Suplai oksigen merupakan hal penting dalam proses degradasi bahan organik dan pertumbuhan bakteri, 
kekurangan oksigen dapat menyebabkan terjadinya kematian pada bakteri. Apabila bakteri yang mati terdapat dalam celah yang kecil maka tidak dapat lepas dari media sehingga akan tetap berada di dalam biofilter, hal ini akan mengakibatkan terjadinya penambahan beban organik dan amonia di dalam reaktor (Said \& Ruliasih, 2005).

Dalam pemilihan media penyangga terdapat beberapa kriteria media biofilter yang perlu diperhatikan salah satunya yaitu diameter celah bebas yang besar (Large free passage diameter). diameter celah bebas dapat dijelaskan dengan membayangkan ukuran partikel yang paling besar yang dapat melewati media (Kemenkes RI, 2011). Berdasarkan penelitian Said (2005) yang mempergunakan media filter berbahan serat plastik dengan bentuk kemoceng dengan ukuran tinggi $16 \mathrm{~cm}$ dan diameter $5 \mathrm{~cm}$. media tersebut disusun di dalam bak dengan ukuran diameter $28 \mathrm{~cm}$, tinggi 28 cm dengan volume efektif 12,92 liter diisi dengan 5-6 susunan serat plastik. Dalam penelitian tersebut diperoleh persentase efisiensi penghilangan BOD 73,24 - 94,92\% dan penghilangan COD 65,80-90,76\%.

Sedangkan media filter dalam penelitian ini mempergunakan serat ijuk yang disusun secara vertikal dengan tinggi $25 \mathrm{~cm}$ dan diameter serat $0,5 \mathrm{~cm}$ kemudian serat tersebut disusun di plat plastik dengan panjang $35 \mathrm{~cm}$ dan lebar 25 Jarak setiap serat pada plat plastik tersebut $\pm 0,5$ $\mathrm{cm}$, sehingga saat serat disusun di plat plastik memiliki jarak yang rapat antara serat satu dengan serat yang lain. Pada penelitian ini susunan serat ijuk yang yang dipakai sebagai media filter memiliki celah bebas yang sempit, sedangkan penelitian yang dilakukan oleh said susunan media filternya memiliki susunan celah yang lebih luas. Media filter yang terbuat dari bahan serat atau fiber memiliki kemampuan yang baik apabila dipergunakan sebagai filter fisik atau sebagai filter biologis. Namun, penggunaan media filter dengan bahan serat memiliki kelemahan dimana bahan serat memiliki diameter celah bebas yang kecil dan cenderung cepat tersumbat, sehingga efektivitas pengolahan berkurang (Sholichin, 2012)

Pada penelitian yang dilakukan waktu HRT yang dipergunakan adalah 24 jam dimana air limbah yang berada di dalam reaktor untuk melewati seluruh proses memerlukan waktu selama 24 jam. Apabila dilihat dari rancangannya, reaktor yang dipergunakan memiliki 3 kompartemen sehingga waktu tinggal air limbah di setiap kompartemen yaitu selama 8 jam. Jadi dapat diketahui bahwa dalam proses pengolahan air limbah pada penelitian ini kontak antara air limbah dengan mikroorganisme yang terbentuk pada biofilter hanya memiliki waktu selama 8 jam. Penelitian yang dilakukan oleh Rekoyoso (2014), dimana dalam proses pengolahan air limbah pada penelitian tersebut menerapkan variasi HRT 4 jam, 8 jam, 10 jam dan 12 jam. Dari penelitian tersebut dapat diketahui bahwa efisiensi penyisihan COD dan BOD menjadi semakin besar, dengan HRT 12 jam sebagai titik optimum. Apabila HRT yang dipergunakan lebih lama, maka akan memberikan kesempatan kontak lebih 
lama antara biofilm dengan air limbah, sehingga proses degradasi bahan organik dapat berjalan dengan baik (Nugrahini dkk., 2008).

Dari persentase efektivitas penurunan nilai parameter BOD, COD dan TDS didapat rata-rata persentase efektivitas sistem pada masing-masing reaktor. Efektivitas sistem yang diperoleh selama 5 minggu pengujian memiliki nilai rata-rata sebesar 33,05\%, dengan persentase efektivitas penurunan parameter pencemar antara lain: BOD sebesar $46,47 \%$, COD sebesar 39,88\%, TDS sebesar $12,81 \%$. Berdasarkan hasil tersebut penggunaan ijuk sebagai media biofilter dalam penelitian ini belum efektif dalam mengolah limbah cair domestik hotel. Namun dalam penelitian yang dilakukan hasil dari proses pengolahan air limbah memiliki nilai parameter yang sudah sesuai dengan kriteria standar baku mutu yang berlaku.

Pada penelitian yang dilakukan terdapat beberapa kelemahan dimana air limbah yang dipergunakan memiliki kualitas yang fluktuatif, temperatur lingkungan yang berubah-ubah, kondisi selang aerator yang mengalami penyumbatan akibat pengendapan lumpur di dasar reaktor, dan penyusunan media yang rapat

\section{SIMPULAN}

Serat ijuk dapat dipergunakan sebagai media biofilter untuk mengolah limbah cair domestik, namun dalam penelitian ini belum memperoleh hasil yang maksimal.

Pada penelitian ini terdapat beberapa faktor yang mempengaruhi E-mail korespondensi: herrypurnama@unud.ac.id kinerja reaktor seperti penyusunan serat ijuk yang terlalu rapat sehingga diameter celah bebas menjadi sempit dan rentan mengalami penyumbatan, selang aerator yang tersumbat berpengaruh terhadap suplai oksigen dalam reaktor, penempatan reaktor di luar ruangan mengakibatkan reaktor terkena hujan dan mengalami perubahan temperatur, terhambatnya suplai oksigen, serta adanya perubahan kondisi limbah yang berakibat pada penurunan suplai nutrisi untuk organisme yang terdapat di dalam reaktor.

Berdasarkan hasil penelitian yang dilakukan dapat diketahui bahwa dari keseluruhan reaktor rata-rata persentase efektivitas pengurangan BOD yaitu sebesar $46,48 \%$, COD sebesar 39,88\%, dan TDS sebesar $12,81 \%$. Efektivitas sistem yang diperoleh selama 5 minggu pengujian memiliki nilai rata-rata sebesar 33,05\% maka dapat disimpulkan bahwa penggunaan ijuk sebagai media biofilter untuk mengolah limbah cair domestik pada penelitian ini belum efektif. Namun apabila dilihat dari hasil pengolahan setiap minggunya nilai parameter pencemar mengalami penurunan dan sudah memenuhi kriteria standar yang ditetapkan pada Peraturan Gubernur Bali No. 16 Tahun 2016.

\section{SARAN}

Tata cara dalam melakukan pemilihan dan penyusunan media biofilter perlu memperhatikan aspek-aspek yang dapat mempengaruhi kinerjanya seperti memiliki permukaan spesifik yang besar, fraksi volume rongga yang tinggi, diameter celah bebas yang besar, tahan terhadap penyumbatan memiliki kekuatan mekanik 
yang baik, fleksibel, ringan, memiliki sifat kebasahan, dapat mereduksi cahaya.

Perlu dilakukan kajian lebih lanjut terkait penggunaan ijuk sebagai media biofilter dalam pengolahan air limbah, mengingat dalam penelitian ini proses pengolahan belum berjalan dengan maksimal dan terdapat berbagai faktor yang mempengaruhi proses pengolahan.

\section{UCAPAN TERIMA KASIH}

Terima kasih kepada bapak I Gede Herry Purnama,ST.,MT.MIDEA atas bimbingannya selama penelitian ini dilaksanakan serta staf CV. Alam Raya yang telah membantu melancarkan dan mendukung penelitian ini sampai selesai dilaksanakan.

\section{DAFTAR PUSTAKA}

Budiarta, I. G. (2014). Penegakan Sanksi Terhadap Pelanggaran Baku Mutu Limbah Cair Hotel Menurut Undang-Undang Nomor 32 Tahun 2009 Sebagai Antisipasi Kemerosotan Kualitas Lingkungan Pantai Di Bali. Media Komunikasi Geograf, 15(2), pp. 17-28.

Grady, C.P.L and Lim, H.C. (1980). Biological Wastewater Treatment. Marcel Dekker Inc. New York.

Kementerian Kesehatan RI. (2011). Pedoman Teknis Instalasi Pengolahan Air Limbah Dengan Sistem Biofilter Anaerob Aerob Pada Fasilitas Pelayanan Kesehatan.

Mara, D. (2004) Domestic Wastewater Treatment in Developing Countries. London: Earthscan.

Mishra, T., Ramola, S. and Shankhwar, A. K. (2015). Desalination and Water
Treatment Pulp and paper mill effluent treatment by hybrid anaerobic upflow fixed-bed bioreactor combined with slow sand filter. Journal Desalination and Water Treatment, 57(23). doi: 10.1080/19443994.2015.1039596.

Nugrahini, P., 2008, Penentuan Parameter Kinetika Proses Anaerobik Campuran Limbah Cair Industri Menggunakan Reaktor UASB, Seminar Nasional Sains dan Teknologi-II, Universitas Lampung. Pitoyo, P. N. P., Arthana, I. W. and Sudarma, I. M. (2016). Kinerja Pengelolaan Limbah Hotel Peserta Proper Dan Non Proper Di Kabupaten Badung, Provinsi Bali. ECOTROPHIC, 10(1), pp. 33-40.

Rarasari, D. M. G., Restu, I. W. and Ernawati, N. M. (2019). Efektivitas Pengolahan Limbah Domestik di Instalasi Pengolahan Air Limbah ( IPAL ) Suwung-Denpasar , Bali. Journal of Marine and Aquatic Sciences. 5, pp. 153-163.

Rekoyoso, Bonis, et al. (2014) Pengaruh Hydraulic Retention TIME (Hrt) Dan Konsentrasi Influen Terhadap Penyisihan Parameter Bod Dan Cod Pada Pengolahan Limbah Domestik Greywater Artificial Menggunakan Reaktor Uasb. Jurnal Teknik Lingkungan, vol. 3, no. 1, pp. 1-7

Said, N. I. and Ruliasih (2005). Tinjauan Aspek Teknis Pemilihan Media Biofilter Untuk Pengolahan Air Limbah. JAI, 1(3), pp. 272-281.

Said, N. I. (2005). Penggunaan Media Serat Plastik Pada Proses Biofilter 
Tercelup. 1(2), pp. 143-156.

Sholichin, M. (2012) Pengolahan Limbah Cair. Universitas Brawijaya.

Slamet, A,. dan Masduqi, A. 2002. Satuan Operasi. Surabaya : Jurusan Teknik Lingkungan FTSP ITS

Widyawati. (2011). Sukses Investasi Massa Depan Dengan Bertanam Pohon Aren. Yogyakarta : Lily Publisher
Yuliani, E. (2018). Efektivitas Biofilter Bermedia Kerikil, Pasir, Ijuk, Botol Plastik Dan Kiapu (Pistia Stratiotes) Dalam Menurunkan Kadar BOD5, COD Pada Limbah Cair Mie Basah. pp. 1-9. 
Arc. Com. Health Agustus 2021

p-ISSN 2302-139X e-ISSN 2527-3620

Vol. 8 No. 2: 360 - 371

\section{Lampiran}

\section{Tampak Samping}

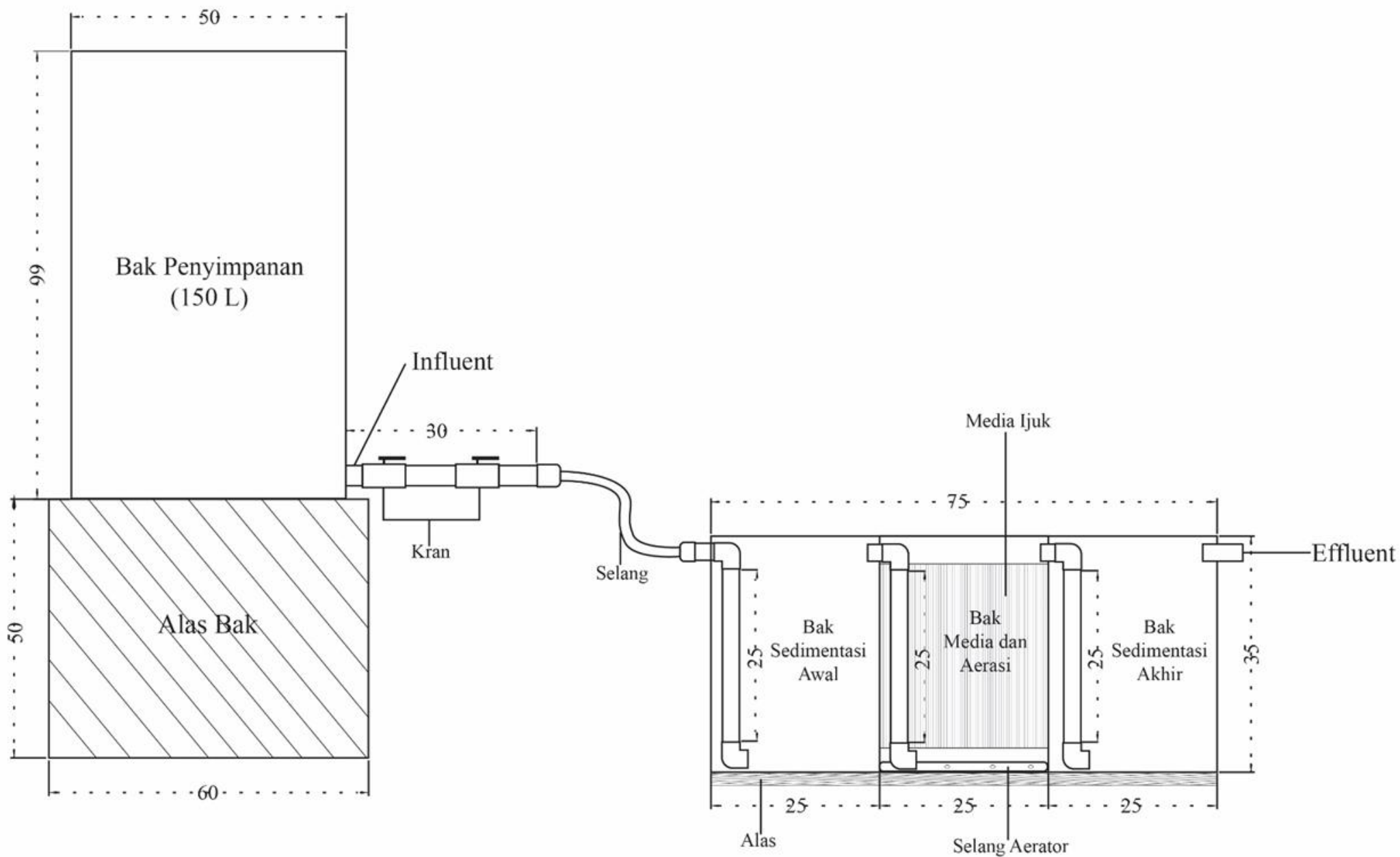




\section{Tampak Atas}

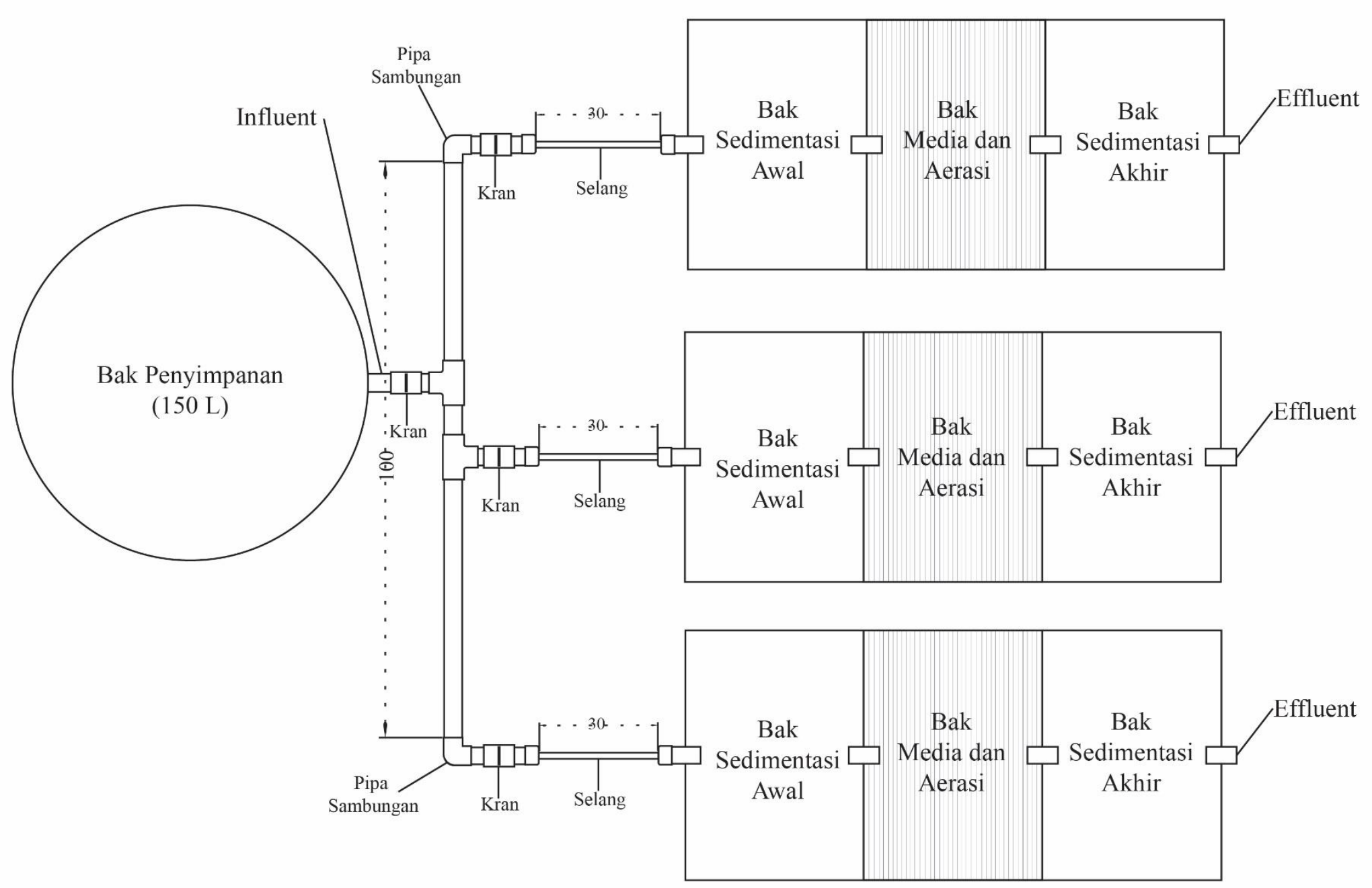

